\title{
Heavy Metal Concnetrations in Sediment and Periwinkle -Tympanotonus fuscastus in the Different Ecological Zones of Bonny River System, Niger Delta, Nigeria
}

\author{
Chindah, A. C., ${ }^{1, *}$ Braide, S. A., ${ }^{2}$ Amakiri, J. and Chikwendu, S.O.N ${ }^{1}$ \\ ${ }^{1}$ Institute of Pollution Studies, Rivers State University of Science and Technology, Nkpolu Oroworukwo, P M B 5080, \\ PortHarcourt, Rivers State, Nigeria \\ ${ }^{2}$ Plant Science and Biotechnology, University of Port PortHarcourt, Portharcourt
}

\begin{abstract}
Studies of total hydrocarbon concentrations (THC) and heavy metals was conducted at the Bonny /New Calabar River in order to determine the level of these contaminants (from municipal and industrial sources) on sediment and important biological organism in the environment in September 2000 for wet and January 2001 for dry seasons. The study area is within the eastern arm of the Niger Delta located between longitude 4025 " to 4040 " N and latitude 7025 " to $7015 " \mathrm{E}$. In the 3 ecological areas studied, the distribution of THC was found to be higher in dry season $(411.53 \pm$ $118.77 \mathrm{mg} / \mathrm{l}$ than wet $(400 \pm 375.50 \mathrm{mg} / \mathrm{l})$. Similarly differences were found in the heavy metals distribution in the river system. The magnitude was in the decreasing order of $\mathrm{Zn}>\mathrm{Cu}>\mathrm{Pb}>\mathrm{V}>\mathrm{Cd}>\mathrm{Cr}>\mathrm{Cd}$ respectively. This pattern was consistent for all the ecological zones. Bioaccumulation studies also showed that the Tympanotonus fuscatus tissue had more THC and metal contaminants than the sediment. Although the heavy metal values obtained were less than the regulatory standards, the continued accumulation of the contaminants is a cause for concern. THC in both sediment and tissue are high enough to affect the quality of the organism for human consumption.
\end{abstract}

Keywords: Tympanotonus fuscatus, Heavy metal, Total hydrocarbon concentrations, Bonny River, Niger Delta.

\section{INTRODUCTION}

Increasing industrial activities over recent decades have regularly introduced heavy and toxic metals, fertilizers or pesticides in any ecosystem [1-6]. At the same time, significant amounts of municipal and agricultural wastes are discharged into the environment. Once released, these pollutants enter atmospheric and hydrological circulation and are finally deposited on river beds, back swamps, and in the marine environment where both lacustrine and marine sediments, continuously enriched by all kinds of pollutants, become a sink indicating the past history of contamination [6-9,53].

Therefore, the investigation of the vertical distribution of the pollutants in sediment cores can furnish useful information concerning these processes.

For the marine monitoring studies of sedentary organisms, widely distributed geographical studies capable of accumulating metals, so as to reflect the environmental conditions, are employed. Gastropod molluscs, especially Tympanotonous fuscatus fulfil all the requirements, this can therefore, act appropriatelyas a biological indicator of pollution [10-12]. Its suitability is universally recognized, being included in most of the national environmental monitoring

*Address correspondence to this author at the Institute of Pollution Studies, Rivers State University of Science and Technology, Nkpolu Oroworukwo, P M B 5080, PortHarcourt, Rivers State, Nigeria;

E-mail: alexchindah@yahoo.com programmes of marine and brackish water pollution [13]. These organisms accumulate most of the contaminants at much higher levels than those found in the water column and they are representative of the pollution of an area, hence can be used to monitor the quality of coastal waters. The gastropods have long been regarded as promising bio-indicators and bio-monitoring subjects. They are abundant in many brackish aquatic ecosystems as in the Niger Delta, being easily available for collection. They are highly tolerant to many pollutants and exhibit high accumulation of them, particularly heavy metals.

The objective of this study was to determine the suitability, in terms of health and safety, of the mollusk species, namely Tympanotonous fuscatus as sources of food and to determine the potential of using these three mollusk species as biomonitors for heavy metal pollution in freshwater ecosystems.

In this work the levels of the different heavy metals in different ecological zones and the uptake of the gastropod species Tympanotonous fuscatus within the ecotype of the estuary are compared.

\section{STUDY AREA}

The study area stretched from lower reach of Bonny River at Bonny town by Peterside community to Choba town in the upper reach of the New Calabar River. The entire stretch from the Bonny to Choba is largely influenced by the tidal cycles, about $20 \mathrm{~km}$, lies between longitude $7^{\circ} 00^{\prime \prime}$ to $7^{\circ}$ $15^{\prime \prime} \mathrm{E}$ and latitude $4^{\circ} 25^{\prime \prime}$ to $4^{\circ} 45^{\prime \prime} \mathrm{N}$ (Fig. 1). The tidal am- 


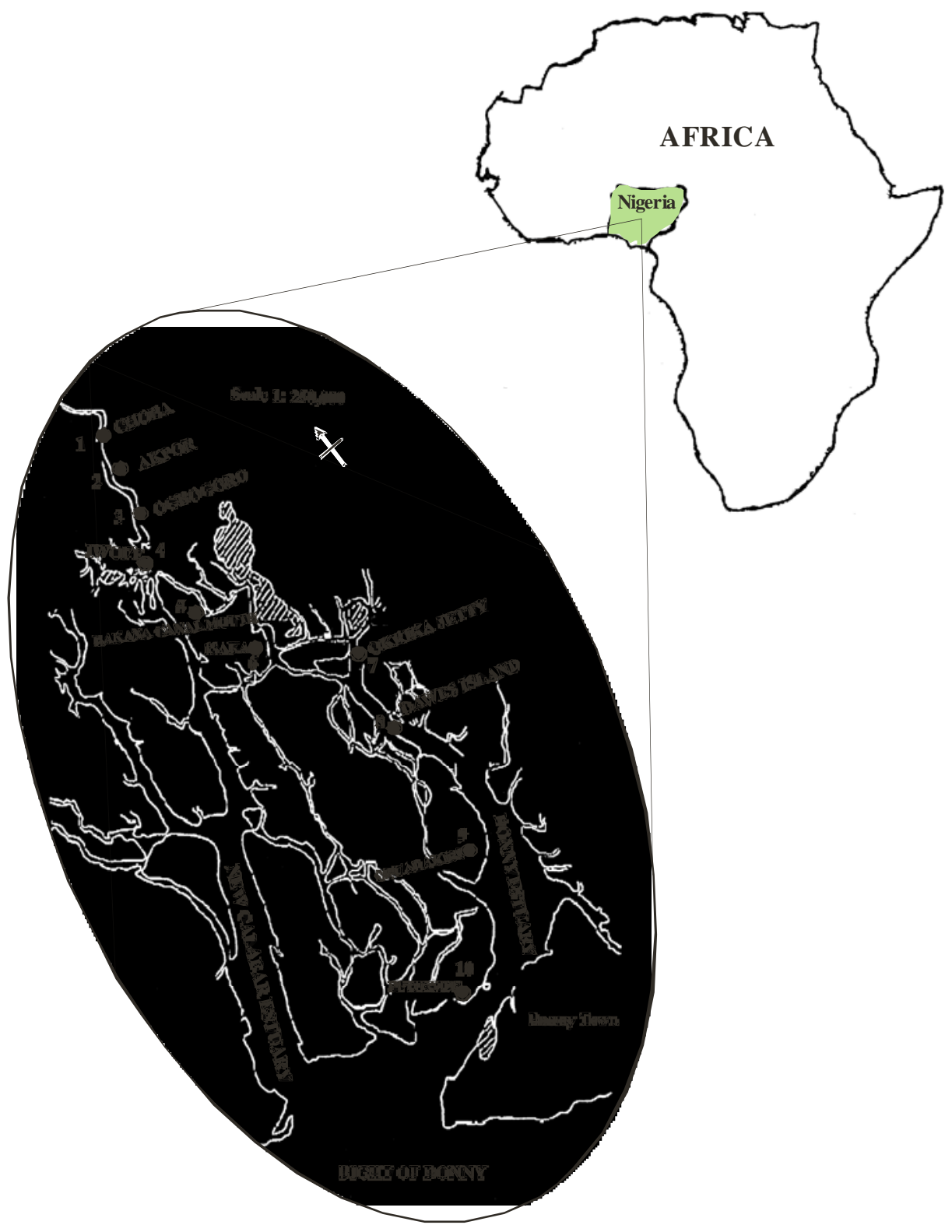

Fig. (1). Map of Africa, Nigeria, showing the sampling stations in Bonny New-Calabar Estuary.

plitude is generally high and above $2 \mathrm{~m}$ at the Bonny terminal jetty [14] However, the water level increases and decreases depending on the lunar cycle. At high tides, salinity increases and decreases at low tides. Sea influence is experienced more at high tide regime than at low tide, when the effect decreases especially within the upper limits when fresh water input dominates the zone [15]. The climatic condition is humid typical of the semi hot equatorial type [16, 17]. The area experiences heavy rainfall from April to October and sporadic rainfalls are experienced during the dry season months of November to March. The mean annual rainfall is estimated to be about 2,405 $\mathrm{mm}$ [17].

Ten (10) sampling stations were located in three (3) ecological zones (Upper, middle and lower) reaches of the systems as follows:

Stations 1-3 are within the Upper limits where industrial activity and salinity influence are low (oilgohaline). The vegetation is mixed, comprising mangrove (Rhizophora racemosa, R. mangle, Avicennia africana and Phoenix reclineata) and fresh water flora Dalbergia sp., Drepanocarpus spp. Ralphia spp. and Pandanus spp [15].

The middle reach stations [18-21] lie within the mesopolyhaline limit with several activities especially from municipal and industrial discharges from Port Harcourt Refinery and related activities. The vegetation is predominantly mangrove especially $R$. racimosa, $R$. mangle, Avicennia africana, Laguncularia.racemosa [8].

While the lower limit lies towards the Bonny River mouth receiving discharges from the middle reach and oil related activities such as flow stations, crude oil Tank farm, condensate plant, and liquefied natural gas plant (NLNG). This zone is also essentially polyhaline in nature all the year round. The vegetation is mangrove dominated by $R$. 
racimosa, $R$. mangle, Avicennia africana, Lagunculena. recemosa and Acristichum aureum [8].

\section{MATERIALS AND METHODS}

\section{Sampling Strategy}

Sediment and periwinkle samples were collected in wet (September 2000) and dry (January 2001) seasons from the 10 stations along the Bonny/New Calabar estuary based on the ecological settings and human activities. The parameters studied in each station were sediment and biological variables- Tympanotonous fuscatus.

\section{Sediment}

Sediment samples for total hydrocarbon were randomly collected at each station from the mid intertidal flats during low tide regime from during low tide from the mid intertidal limits of the stations. At each station, three (3) replicates of sediment samples were collected at surface layer $(0-15 \mathrm{~cm}-$ depth) using soil augers. The three (3) replicate samples were composed and placed in an aluminum foil for hydrocarbon analysis, and another set of replicates for metal analysis were placed in cellophane bags. All samples were immediately stored in an icebox $\left(-10^{\circ} \mathrm{C}\right)$ before transferring to the laboratory. Samples were air dried for about three (3) weeks. Five (5) $\mathrm{g}$ of air dried, ground and sieved through a $200 \mu \mathrm{m}$ mesh size, soil samples, were weighed into a conical flask and $10 \mathrm{mls}$ of toluene added. This was shaken for about 1 minute and filtered using ashless filter paper. The filtrate was measured in a spectronic 21D at $420 \mathrm{~nm}$. Metal samples were analyzed by mixing $4 \mathrm{~g}$ of finely ground soil samples and $50 \mathrm{ml}$ of distilled water in a platinum crucible. $10 \mathrm{ml}$ of concentrated Hydrochloric (HCL) acid and $2 \mathrm{ml}$. of concentrated Nitric acid $\left(\mathrm{HNO}_{3}\right)$ were added in succession. The mixture was heated in a steam bath to a thick yellow liquid. The crucible was allowed to cool down; its content filtered through a membrane filter $(0.5 \mu \mathrm{m})$. and made up to $100 \mathrm{ml}$ with distilled water. The extract was stored in plastic bottles and analyzed using atomic absorption spectrophotometer (AAS -Perkin Elmmer, 3110 Model). Using the certified reference material (ACCU TRACE(TM) for AAS) as a reference, Solvent blanks and duplicate samples were also analyzed. The variation coefficient of concentrations between duplicate samples was less than $5 \%$.

\section{Heavy Metal Analysis}

\section{Mollusc}

Tissue samples weighing $0.5 \mathrm{~g}$ were digested with $6 \mathrm{ml}$ of concentrated nitric acid and $1 \mathrm{ml}$ of $30 \%$ hydrogen peroxide. The digestion was carried out in a microwave digester using the microwave digestion. The completely digested samples were filtered and diluted to $25 \mathrm{ml}$ in volumetric flasks with distilled water.

Ground samples $0.5 \mathrm{~g}$ into the digestion vessels and digested with $2 \mathrm{ml}$ of concentrated nitric acid, $5 \mathrm{ml}$ of concentrated hydrochloric acid and $1 \mathrm{ml}$ of $30 \%$ hydrogen peroxide. The digested contents were filtered and diluted to $25 \mathrm{ml}$ in volumetric flasks. The resulting solutions were analysed for heavy metals commonly associated with crude oil andpetroleum products such such as Chromium $(\mathrm{Cr})$, Cadmium (Cd),
Vanadium (V), Lead ( $\mathrm{Pb})$, Zinc ( $\mathrm{Zn})$, and Copper $(\mathrm{Cu})$ using ICP-AES.

Bioaccumulation factor (BAF) was calculated to determine the level of heavy metal accumulation in the tissue of the organism using the formula below,

$$
\mathrm{BAF}=\frac{\text { Concentration of metals in periwinkle }(\mathrm{mg} / \mathrm{kg})}{\text { Concentration of metals in sediment }(\mathrm{mg} / \mathrm{kg})}
$$

Where in BAF is the ratio of metals concentration in the periwinkle tissue to its concentration in the sediment and seasonal comparison of variables for sediment and periwinkle was carried out using Microsoft Excel package 2003.

\section{RESULTS}

\section{Sediments}

\section{Total Hydrocabon Concentration (THC)}

The concentration of hydrocarbon in the sediments and body tissue of periwinkle for the study stations for wet and dry seasons are presented in Fig. (2a).

Generally, mean total hydrocarbon concentrations (THC) in the sediment were lower in wet than dry season (Fig. 2a). Within the different ecological zones along the river course, the lower reach had higher concentrations of THC in the dry $(307.80-487.07 \times 394.12 \pm 73.34 \mathrm{mg} / \mathrm{kg})$ than in the wet season $(84.56-365.3 \times 156.72 \pm 149.81 \mathrm{mg} / \mathrm{kg})$ and the station differences for THC concentrations were more remarkable in wet season ( $\mathrm{CV}=95.59 \%)$ than in the dry season $(\mathrm{CV}=18.61 \%)$.

In the middle reach, similar seasonal were observed with concentrations of $6.76-358.53 \times 118.38$ of $\pm 140.72 \mathrm{mg} / \mathrm{kg}$ and $246.92-542.27 \times 356.84 \pm 102.88 \mathrm{mg} / \mathrm{kg}$ for wet and dry seasons respectively. The differences between stations were in the magnitude of about 5 folds higher in wet $(118.87 \%)$ while dry season recorded a magnitude of 28.83 $\%$ (Fig. 2a).

At the upper reach, the seasonal pattern of higher values in wet than in dry season were observed as in the other ecological zones ( wet $-0.00-798.25 \times 400.82 \pm 375.50$ $\mathrm{mg} / \mathrm{kg}$; dry season - $287.50-571.63 \times 411 \pm 118.76 \mathrm{mg} / \mathrm{kg}$ ). Nonetheless, the THC were exceptionally low in some of the stations and variations between stations were in the magitude of about 3 folds higher in wet season $(\mathrm{CV}=93.69 \%)$ than in dry season (CV $=28.86 \%)$ Fig. (2a).

In all, a consistent concentration distribution order was observed with a sequence of upper $(400.82 \mathrm{mg} / \mathrm{kg})>$ lower $(156 \mathrm{mg} / \mathrm{kg})>$ middle $(118.38 \mathrm{mg} / \mathrm{kg})$ for wet season and upper $(411.53 \mathrm{mg} / \mathrm{kg})>$ lower $(394.12 \mathrm{mg} / \mathrm{kg})>$ middle $(356.84 \mathrm{mg} / \mathrm{kg}$ ) for dry season (Fig. 2a).

\section{Heavy Metals \\ Chromium (Cr)}

Chromium concentrations in sediment were observed to be higher in wet $(0.01-0.83 \mathrm{mg} / \mathrm{kg})$ than in dry season $(0.002 \mathrm{mg} / \mathrm{kg})$. The lower reach had concentrations in the range of $0.01-0.83 \times 0.37 \pm 0.34 \mathrm{mg} / \mathrm{kg}$ for the wet season with a uniform concentration of $0.02 \mathrm{mg} / \mathrm{kg}$ in the dry sea- 

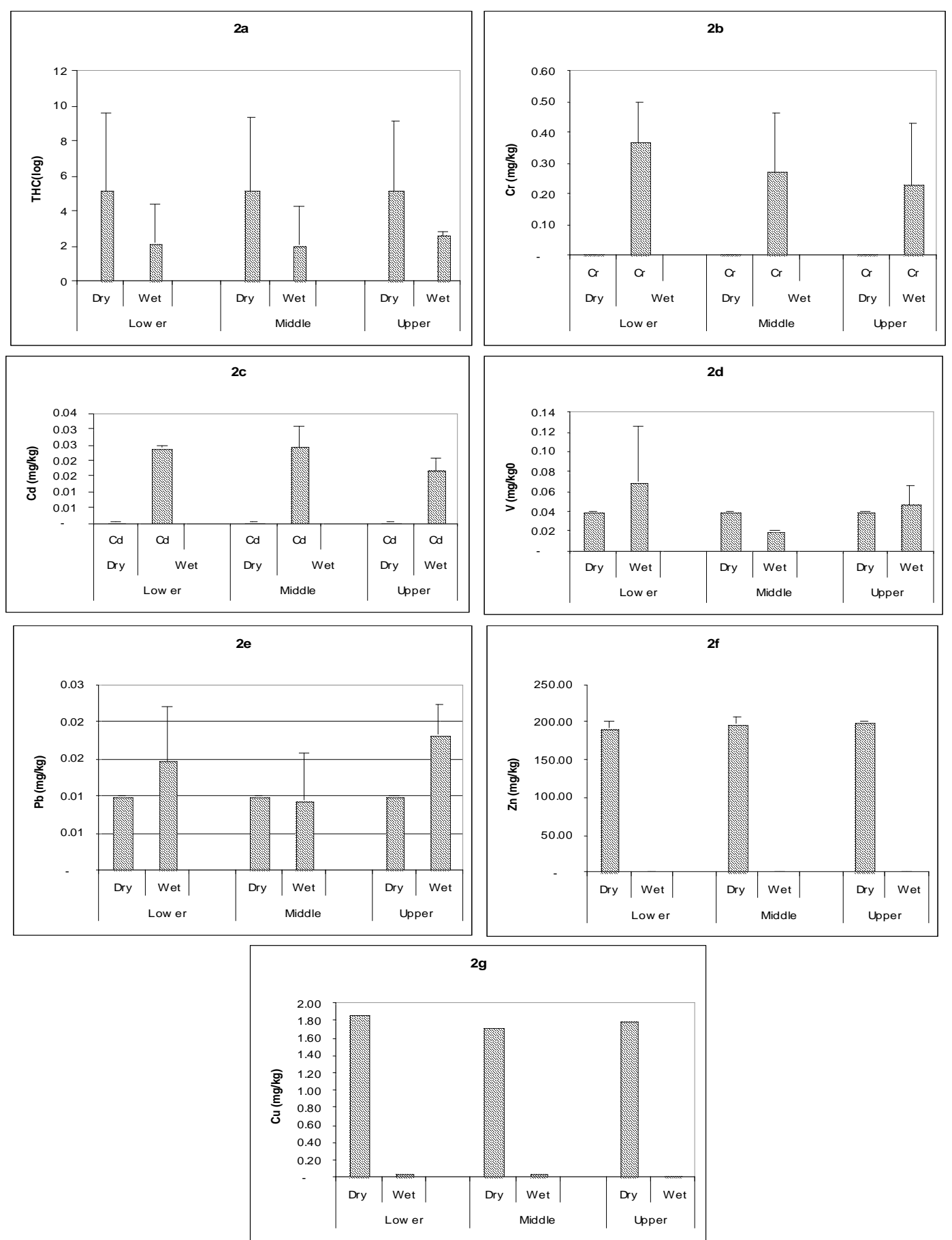

Figs. (2a-g). Total Hydrocarbon and heavy metal concentrations in sediment of the 3 ecological zones.

son. The coefficient of variation for the zone was $92.47 \%$ and $0 \%$ for the wet and dry seasons respectively. In the middle reach zone, similar seasonal trend was observed with concentrations in the range of $0.01-0.55 \times 0.27 \pm 0.19$ $\mathrm{mg} / \mathrm{kg}(\mathrm{CV}=70.13 \%)$ in wet season and uniform concentrations of $0.02 \mathrm{mg} / \mathrm{kg}(\mathrm{CV}=0 \%) \mathrm{mg} / \mathrm{kg}$ in dry season. At the upper reach zone, higher concentrations of chromium were also recorded in the wet $(0.01-0.41 \mathrm{mg} / \mathrm{kg} \times 0.23 \pm 0.17$ $\mathrm{mg} / \mathrm{kg}, \mathrm{CV}=72.1 \%)$ than in the dry season $(0.002 \mathrm{mg} / \mathrm{kg}-$ $\mathrm{CV}=0 \%$ ) seasons. A general trend observed across all the zones showed higher concentrations of chromium in for the wet than in the dry season (Fig. 2b). The mean differences between the zones indicates a distribution order of lower reach $(0.37 \mathrm{mg} / \mathrm{kg})>$ middle limit zone $(0.27 \mathrm{mg} / \mathrm{kg})>$ upper limit zone $(0.23 \mathrm{mg} / \mathrm{kg})$, in the wet season while the dry season maintained uniform low concentration for all the ecological zones (Fig. 2b).

\section{Cadmium (Cd)}

Cadmium had higher concentrations in wet $(0.014$ $0.029 \mathrm{mg} / \mathrm{kg}$ ) than in dry season $(0.0005 \mathrm{mg} / \mathrm{kg})$. In the lower reach, concentrations ranged from $0.015-0.029$ 
$\mathrm{mg} / \mathrm{kg} \times 0.02 \pm 0.01 \mathrm{mg} / \mathrm{kg}(\mathrm{Cv}=26.57 \%)$ while in the dry season values were uniform $(0.005 \mathrm{mg} / \mathrm{kg} \mathrm{CV}=0 \%)$. Within the middle limit, cadmium concentrations ranged from 0.016 - $0.034 \times 0.02 \pm 0.01 \mathrm{mg} / \mathrm{kg}(\mathrm{CV}=26.46 \%)$ and the dry season values were of uniform concentration $(0.0005 \mathrm{mg} / \mathrm{kg}$, $\mathrm{CV}=0 \%$ ) for all the stations. The upper limit zone also had concentrations $0.014-0.022 \times 0.02 \pm 0.00 \mathrm{mg} / \mathrm{kg}(\mathrm{CV}=$ $22.63 \%)$ and $0.0005 \mathrm{mg} / \mathrm{kg}(\mathrm{CV}=0 \%)$ for wet season and in dry season respectively. The distribution pattern for wet and dry seasons were in the order of lower limit zone $(0.02$ $\mathrm{mg} / \mathrm{kg})=$ middle limit zone $(0.02 \mathrm{mg} / \mathrm{kg})=$ upper limit zone $(0.02 \mathrm{mg} / \mathrm{kg})$ and lower $(0.0005 \mathrm{mg} / \mathrm{kg})=$ middle $(0.005$ $\mathrm{mg} / \mathrm{kg})=$ upper $(0.005 \mathrm{mg} / \mathrm{kg})$ respectively (Fig. 2c)

\section{Vanadium $(V)$}

Vanadium (V) concentrations were relatively high for both seasons with slight variations observed between dry $(0.04 \mathrm{mg} / \mathrm{kg})$ and wet season $(0.02-0.13 \mathrm{mg} / \mathrm{kg})$. In the lower limit zone, the wet season concentrations ranged from $0.02-0.13 \times 0.07 \pm 0.05 \mathrm{mg} / \mathrm{kg}(\mathrm{c} \mathrm{v}=64.94 \%)$ while the dry season had concentrations of $x 0.04 \pm 0.00 \mathrm{mg} / \mathrm{kg}(0 \%) \mathrm{Fig}$. (2d). The middle zone, had mean concentrations of 0.02 $\mathrm{mg} / \mathrm{kg}$ and $0.04 \pm 0.00 \mathrm{mg} / \mathrm{kg}$ for wet and dry seasons (Fig. 2d).

The upper limit zone had concentrations of $0.02-0.06$ $x 0.05 \pm 0.02 \mathrm{mg} / \mathrm{kg}$ and $x 0.04$ for the wet and dry seasons respectively. There appeared to be differences in the mean concentrations across the zones such that in wet season, the distribution of the metal was in the order of the lower $(0.07$ $\mathrm{mg} / \mathrm{kg})>$ upper $(0.05 \mathrm{mg} / \mathrm{kg})>$ middle $(0.02 \mathrm{mg} / \mathrm{kg}) \mathrm{mg} / \mathrm{kg}$, while the dry season demonstrated a uniform distribution $(0.04 \mathrm{mg} / \mathrm{kg})$ Fig. (2d).

\section{Lead (Pb)}

Lead concentrations in the sediment were higher in wet $(0.003-0.027 \mathrm{mg} / \mathrm{kg})$ than dry season $(0.01 \mathrm{mg} / \mathrm{kg})$. In the lower limit zone, the wet season concentrations ranged from $0.008-0.023 \times 0.01 \pm 0.01 \mathrm{mg} / \mathrm{kg}(\mathrm{CV}=42.52 \%)$ and in dry season mean concentrations $\vec{x} 0.01 \pm 0.00 \mathrm{mg} / \mathrm{kg}(\mathrm{CV}=0 \%)$ Fig. (2e). In the middle zone, the same trend was observed with the wet season $(0.003$ and $0.02 \mathrm{mg} / \mathrm{kg} \mathrm{CV}=67.61 \%)$ concentrations slightly higher than the dry season $(x 0.01$ $\pm 0.00 \mathrm{mg} / \mathrm{kg}$ ). Contrary to the trend in the middle limit zone, the upper limit zone recorded higher values during the wet ( $0.01-0.027 \times 0.02 \pm 0.01 \mathrm{mg} / \mathrm{kg} ; \mathrm{CV}=37.88 \%)$ than in the dry season $(0.01 \pm 0.00 \mathrm{mg} / \mathrm{kg} ; \mathrm{CV}=0 \%)$. A general trend observed across the zones indicated higher concentrations of the metal $(\mathrm{Pb})$ in wet than in the dry season (Fig. 2e). The distribution between the ecological zone for wet season was in the sequence of upper limit zone $(0.02)>$ middle limit zone > lower limit zone $(0.01) \mathrm{mg} / \mathrm{kg}$, while the dry season showed a uniform concentration for the zones (upper limit zone $-0.01 \mathrm{mg} / \mathrm{kg}$ ) = middle limit zone $-0.01 \mathrm{mg} / \mathrm{kg}$ ) = lower limit zone $-0.01 \mathrm{mg} / \mathrm{kg}$ ) Fig. (2e).

\section{Zinc (Zn)}

Zinc concentrations in the sediment were observed to be higher in dry $(1.03-2.04 \mathrm{mg} / \mathrm{kg})$ than in wet season $(0.063$ $0.277 \mathrm{mg} / \mathrm{kg}$ ). In the lower limit zone, concentrations were in the range of $0.107-0.232 \times 0.17 \pm 0.05 \mathrm{mg} / \mathrm{kg}(\mathrm{CV}=29.36$ $\%)$ in the wet season while the dry season concentrations ranged from $1.09-1.78 \times 1.42 \pm 0.28 \mathrm{mg} / \mathrm{kg}(\mathrm{CV}=19.82 \%)$ Fig. (2f). In the middle limit zone of the river, ranged from $0.154-0.245 \bar{x} 0.19 \pm 0.03 \mathrm{mg} / \mathrm{kg}(\mathrm{CV}=18.72 \%)$ for the wet season while the dry season concentrations ranged from $1.13-1.83 \times 1.48 \pm 0.26 \mathrm{mg} / \mathrm{kg}(\mathrm{CV}=17.79 \%)$. The upper limit zone of the river recorded concentrations in the ranged of $0.197-0.277 \times 0.18 \pm 0.09(\mathrm{CV}=49.32 \%)$ while the dry season value ranged from $1.03-2.04 \times 1.39 \pm 0.46 \mathrm{mg} / \mathrm{kg}$ $(\mathrm{CV}=33.13 \%)$. However, unlike other metals, $\mathrm{Cr}, \mathrm{Cd}, \mathrm{Cu}$, and $\mathrm{Zn}$ concentrations were higher in the dry than in the wet season by a magnitude order of about 8 times. There were obvious differences in distribution of the zinc concentrations across the river system such that wet season distribution was in the order of the middle limit zone $(0.19 \mathrm{mg} / \mathrm{kg})>$ upper limit zone $(0.18 \mathrm{mg} / \mathrm{kg})>$ lower limit zone $(0.17 \mathrm{mg} / \mathrm{kg})$, and dry season, had similar concentration order of middle limit zone $(1.48 \mathrm{mg} / \mathrm{kg})>$ lower limit zone $(1.42 \mathrm{mg} / \mathrm{kg})>$ upper limit zone (1.39 mg/kg) Fig. (2f).

\section{Copper $(\mathrm{Cu})$}

Generally, the concentrations of Copper in the sediment were higher in dry $(0.001-0.20 \mathrm{mg} / \mathrm{kg})$ than in thewet season $(0.007-0.057 \mathrm{mg} / \mathrm{kg})$. In the lower limit zone, $\mathrm{Cu}$ concentrations ranged from $0.036-0.039 \times 0.04 \pm 0.0 \mathrm{mg} / \mathrm{kg}$ (cv $=3.31 \%)$ and $0.09-0.11 \times 1.30 \pm 0.05 \mathrm{mg} / \mathrm{kg}(\mathrm{CV}=35.88)$. for wet and dry seasons respectively (Fig. 2g). In the middle limit zone, concentrations ranged from $0.019-0.057 \bar{x} 0.03$ $\pm 0.02 \mathrm{mg} / \mathrm{kg}(\mathrm{CV}=47.71 \%)$ for the wet season while the dry season values ranged from $0.01-0.2 \times 0.12 \pm 0.08$ $\mathrm{mg} / \mathrm{kg}(\mathrm{CV}=71.31 \%)$. The upper limit zone, had a range of $0.07-0.044 \times 0.03 \pm 0.02 \mathrm{mg} / \mathrm{kg}(\mathrm{CV}=54.71 \%)$ and $0.001-$ $0.14 \times 0.06 \pm 0.06 \mathrm{mg} / \mathrm{kg}(\mathrm{CV}=105 \%)$ for the wet and dry seasons respectively (Fig. 2g). Contrary to the trend observed for zinc, copper concentrations were higher in the wet than dry season. Nonetheless, differences in concentrations between the ecological zones were minimal with a distribution order of the lower $(0.040 \mathrm{mg} / \mathrm{kg})>$ middle $(0.03 \mathrm{mg} / \mathrm{kg})$ $=$ upper $(0.03 \mathrm{mg} / \mathrm{kg})$ in wet season with a shift in concentration during the dry season, which occurred in the sequence of lower $(0.13 \mathrm{mg} / \mathrm{kg})>$ middle $(0.12 \mathrm{mg} / \mathrm{kg})>$ upper $(0.06$ $\mathrm{mg} / \mathrm{kg}$ ).

All variables (THC and heavy metals) for sediment demonstrated significant differences between wet and dry seasons exception of Vanadium and Lead (Table 1).

\section{BIOLOGICAL TISSUE STUDIES}

\section{Total Hydrocabon Content the (in Periwinkles tissue- Tympanotonus fuscatus)}

The concentration and magnitude of THC in periwinkle varied between zones and seasons. The concentrations varied from $1,704.73-4,170.50 \mathrm{mg} / \mathrm{kg}$ in the wet and 1,610.02 $2,428.56 \mathrm{mg} / \mathrm{kg}$ in the dry seasons (Fig. 3a). In the lower stretch, the concentrations ranged from 1,704.73 - 3,764.61 $x$ $2,448.86 \pm 933.04 \mathrm{mg} / \mathrm{kg}$ for the wet season while the dry season concentrations were in the range of 1,975.32 $2,151.21 \times 2,073.41 \pm 73.23 \mathrm{mg} / \mathrm{kg}$ (Fig. 3a).

In the middle limit zones, similar concentration trend of higher values in the wet than dry season was observed. Thus the wet season concentrations ranged from 2,120.75 $3,358.72 \times 2,747.35 \pm 591.78 \mathrm{mg} / \mathrm{kg}(\mathrm{CV}=21.5 \%)$ while the 
Table 1. The Bioaccumulation Factor for Total Hydrocarbon and Heavy Metals in the 3 Ecological Zones During Wet and Dry Season for Periwinkle (Tympanotonus fuscastus)

\begin{tabular}{|c|c|c|c|c|c|c|}
\hline \multirow{2}{*}{ Parameters } & \multicolumn{2}{|c|}{ Lower Ecological Zone } & \multicolumn{2}{c|}{ Middle Ecological Zone } & \multicolumn{2}{c|}{ Upper Ecological Zone } \\
\cline { 2 - 7 } & Dry & Wet & Dry & Wet & Dry & 0.015 \\
\hline \hline $\mathrm{THC}$ & 0.014 & 15.626 & 0.014 & 23.207 & 1 & 0.043 \\
\hline $\mathrm{Cr}$ & 0 & 0.027 & 0 & 0.349 & 0.454 & 1 \\
\hline $\mathrm{Cd}$ & 0 & 0.333 & 0 & 0 & 0.429 \\
\hline $\mathrm{V}$ & 0 & 0.286 & 0 & 3.947 & 1 & 1.873 \\
\hline $\mathrm{Pb}$ & 0 & 2.136 & 0 & 1.751 & 0.013 & 1.974 \\
\hline $\mathrm{Zn}$ & 0.016 & 2.233 & 0.013 & & 1 \\
\hline
\end{tabular}

dry season concentrations ranged from 1,610.02 - 2,070.03 $x 1,893.30 \pm 187.97 \mathrm{mg} / \mathrm{kg}(\mathrm{CV}=9.93 .5 \%)$. In the upper zone, changes in THC concentration were observed between seasons with values in the range of 2,567.24 - 4,170.50 $x 3,368.87 \pm 654.53 \mathrm{mg} / \mathrm{kg}(\mathrm{CV}=19.43 \%)$ while the dry season values ranged from 2,036.20 - 2,428.56 $\bar{x}$ 2,229.00 \pm $160.25 \mathrm{mg} / \mathrm{kg}(\mathrm{cv}=7.19 \%)$ Fig. (3a). The mean differences in THC concentrations between the zones indicated differences in the body tissue of the organism (Tympanotonus fuscatus) across the river system. For instance, in the wet season, the distribution of the THC in the organism was in the order of the upper limit zone $(3,368.87 \mathrm{mg} / \mathrm{kg})>$ middle limit zone $(2,747.35 \mathrm{mg} / \mathrm{kg})>$ lower limit zone $(2,448.86$ $\mathrm{mg} / \mathrm{kg}$ ), while in the dry season, the concentrations varied in the order of upper limit zone $(2,229 \mathrm{mg} / \mathrm{kg})>$ lower limit zone $(2,073.41 \mathrm{mg} / \mathrm{kg})>$ middle limit zone $(1,893.30$ $\mathrm{mg} / \mathrm{kg}$ ). These marked differences in the zonal seasonal mean concentrations indicate that there are significant differences in the distribution of $\mathrm{THC}$ in the organism in the river system between the two major seasons (Fig. 3a).

\section{Heavy Metals}

\section{Chromium (Cr)}

A general trend observed across the zones showed that maximum chromium concentrations occurred during the wet season and minimum concentrations in the dry season. The chromium concentrations ranged form $0.010-0.130 \mathrm{mg} / \mathrm{kg}$ in the wet and uniform concentrations of $0.002 \mathrm{mg} / \mathrm{kg}$ in dry season. In the lower reach, uniform concentration of 0.010 $\mathrm{mg} / \mathrm{kg}$ and $0.002 \pm 0.00 \mathrm{mg} / \mathrm{kg}$ were recorded for the wet and dry season respectively. In the middle reach, similarly trend of higher values in the wet season than in the dry season was observed (Fig. 3b). The concentrations varied from 0.01 $0.13 \mathrm{mg} / \mathrm{kg}$ with a mean of $0.10 \pm 0.05 \mathrm{mg} / \mathrm{kg}$ for the wet season while the dry season values were also a uniform concentration of $0.002 \mathrm{mg} / \mathrm{kg}$ with a mean of $0.002 \pm 0.00$ $\mathrm{mg} / \mathrm{kg}$ within the zone. The coefficient of variation within the zone was $0 \%$ for both seasons. In the upper zone, uniform concentrations of $0.01 x 0.01 \pm 0.01 \mathrm{mg} / \mathrm{kg}$ were recorded for the wet season while the dry season value was $0.002 \times 0.002 \pm 0.00 \mathrm{mg} / \mathrm{kg}$ within the zone. The coefficient of variation within the zone was $0 \%$ for both seasons. There also appear to be mean differences across the zones indicating differences in distribution of the chromium metal in the biological organism (Tympanotonus fuscatus) across the system. For instance, in the wet season, the distribution of the chromium in the organism was in the order of the middle $(0.10)>$ upper $(0.01 \mathrm{mg} / \mathrm{kg})=$ lower $(0.01 \mathrm{mg} / \mathrm{kg})$, while for the dry season showed a uniform distribution $(0.002 \mathrm{mg} / \mathrm{kg})$ Fig. (3a). Generally the ratio of distribution of chromium in the river system was observed to be in the order of 1:10:1 for the lower, middle and upper zones.

\section{Cadmium (Cd)}

Cadmium varied in concentration between seasons and zones. The magnitude of variation differed between the zones. The values ranged between $0.030-0.014 \mathrm{mg} / \mathrm{kg}$ in the wet season while in the dry season, a uniform concentration of $0.0005 \mathrm{mg} / \mathrm{kg}$ was recorded across the entire river system. In the lower zone of the river system, values ranged from $0.006-0.010 \mathrm{mg} / \mathrm{kg} x 0.01 \pm 0.00 \mathrm{mg} / \mathrm{kg}$ for the wet season while the dry season value was a uniform concentration of $0.0005 \mathrm{mg} / \mathrm{kg}$ across the entire zone (Fig. 3c). However, some stations within this limit had very low values which were below the detection limit of the instrument. The coefficient of variation within the zone was $0.00 \%$ and $0.00 \%$ respectively for the wet and dry seasons. In the middle limits of the river, similar trend of higher concentrations in the wet season than in the dry season were observed. The values ranged from $0.007-0.014 \times 0.01 \pm 0.01 \mathrm{mg} / \mathrm{kg}$ for the wet season while the dry season value was a uniform concentration of $0.0005 \mathrm{mg} / \mathrm{kg}$ with in the zone. The coefficient of variation within the zone was $0 \%$ for both seasons. In the upper zone, the same trend of higher values in the wet season than dry season was observed. The wet season values ranged from $0.003-0.013 \times 0.01 \pm 0.00 \mathrm{mg} / \mathrm{kg}$ season while the dry season value was a uniform concentration of $0.0005 \mathrm{mg} / \mathrm{kg}$ with in the zone. The coefficient of variation within the zone was $0 \%$ for both seasons (Fig. 3c).

There appears to be a uniform mean distribution of the metal cadmium across the zones. For wet and dry seasons, the mean distribution of the cadmium in the organism was observed to be $0.01 \mathrm{mg} / \mathrm{kg}$ across the lower, middle and up- 

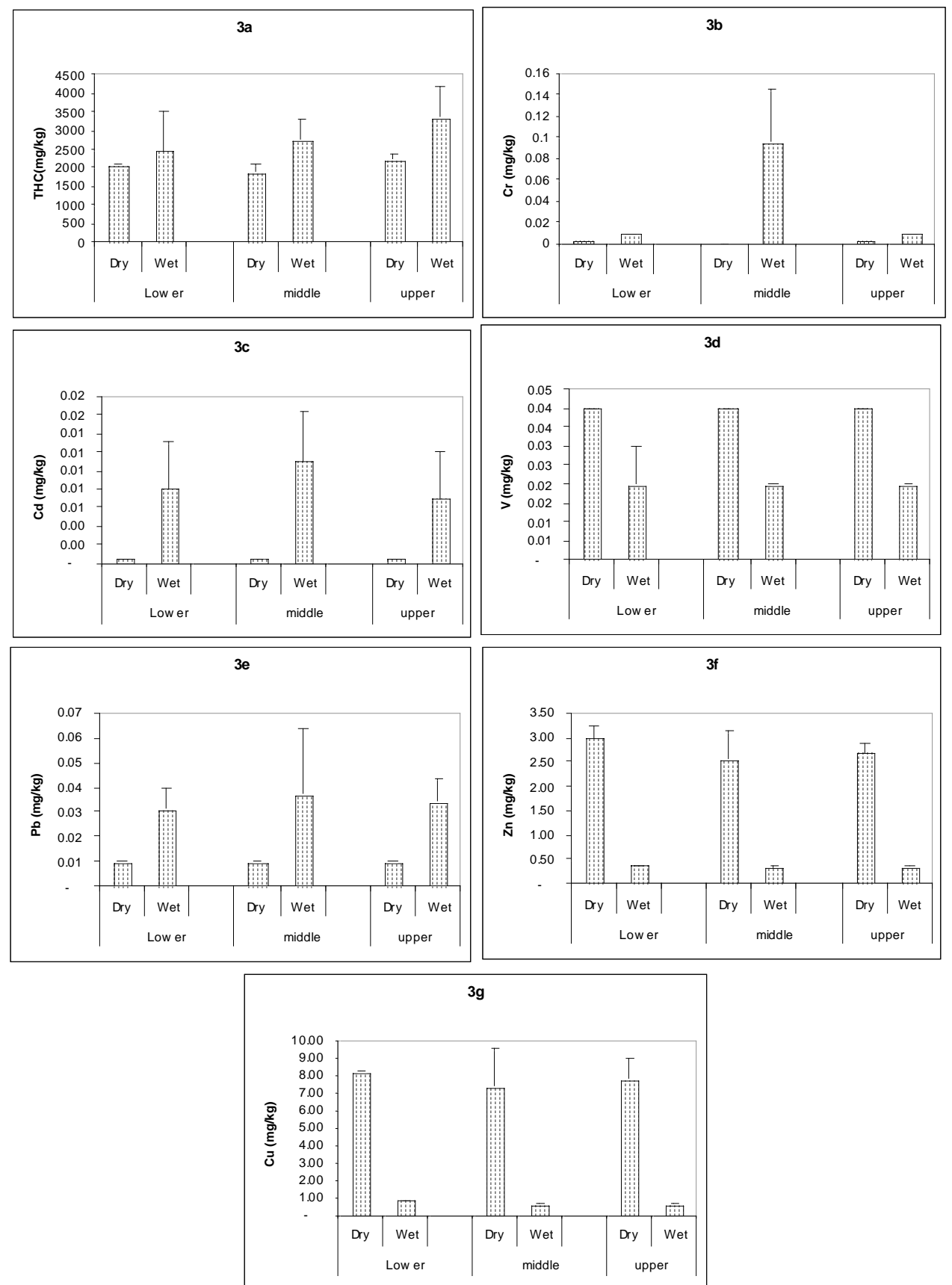

Figs. (3a-g). Total hydrocarbon and heavy metal concentrations in periwinkle Tympanotonus fuscastus tissue from the 3 ecological zones.

per zones, while the dry season also showed a uniform distribution $(0.005 \mathrm{mg} / \mathrm{kg})$ across the entire zones (Fig. 3c).

\section{Vanadium (V)}

The presence of vanadium was prominent in both seasons though at fairly uniform concentrations across the zones of the river for both seasons. The concentration of vanadium ranged from $0.03-0.014 \mathrm{mg} / \mathrm{kg}$ in the wet season while in the dry season, a uniform concentration was recorded across the entire river system (Fig. 3d). In the lower zone, the value for wet season was a uniform concentration of $0.02 \pm 0.01$ $\mathrm{mg} / \mathrm{kg}$ while the dry season value was also uniform $0.04 \pm$ $0.00 \mathrm{mg} / \mathrm{kg}$. The coefficients of variation within the zone were $0.00 \%$ and $0.00 \%$ for both seasons. In the middle zone, a similar trend of higher value in the dry than in the wet season was observed. The wet season value was a uniform concentration of $0.02 \mathrm{mg} / \mathrm{kg}$ with a mean of $0.02 \pm 0.01 \mathrm{mg} / \mathrm{kg}$ while the dry season value was also a uniform at $0.04 \mathrm{mg} / \mathrm{kg}$ with a mean of $0.04 \pm 0.00 \mathrm{mg} / \mathrm{kg}$. The coefficient of variation within the zone was $0 \%$ for both seasons. In the upper zone, a similar trend of higher value in the dry than in the wet season was observed. The wet season value was a uniform concentration of $0.02 \mathrm{mg} / \mathrm{kg}$ with a mean of $0.02 \pm 0.01$ $\mathrm{mg} / \mathrm{kg}$ while the dry season value was also uniform at 0.04 $\mathrm{mg} / \mathrm{kg}$ with a mean of $0.04 \pm 0.00 \mathrm{mg} / \mathrm{kg}$. The coefficient of variation within the zone was $0 \%$ for both seasons. Like 
chromium there seem to be no mean differences in the distribution of the vanadium metal across the zones of the river system for both season (Fig. 3d). In wet season, a uniform mean distribution of vanadium in the organism was observed to be $0.02 \mathrm{mg} / \mathrm{kg}$ while the dry season also showed a uniform distribution (0.04 mg/kg) Fig. (3d).

\section{$\operatorname{Lead}(\mathrm{Pb})$}

The concentrations of lead in periwinkle tissue were higher during the wet than during the dry season. The values varied between $0.009-0.75 \mathrm{mg} / \mathrm{kg}$ in wet season while the dry season recorded a uniform concentration of $0.01 \mathrm{mg} / \mathrm{kg}$ across the entire river system. In the lower reach zone, the wet season values ranged from $0.019-0.046 \mathrm{mg} / \mathrm{kg}$ with a mean of $0.03 \pm 0.01 \mathrm{mg} / \mathrm{kg}$ while the dry season value was also uniform at $0.01 \mathrm{mg} / \mathrm{kg}$ with a mean of $0.01 \pm 0.00$ $\mathrm{mg} / \mathrm{kg}$ (Fig. 3e). The coefficient of variation within the zone was $35.57 \%$ and $0 \%$ respectively for the wet and dry seasons. In the middle reach, a similar trend of higher values in the wet than dry season was observed. The wet season concentrations ranged from $0.009-0.075 \mathrm{mg} / \mathrm{kg}$ with a mean of $0.040 \pm 0.03 \mathrm{mg} / \mathrm{kg}$ while the dry season value was also uniform at $0.01 \mathrm{mg} / \mathrm{kg}$ with a mean of $0.01 \pm 0.00 \mathrm{mg} / \mathrm{kg}$. The coefficients of variation within the zone were $70.19 \%$ and $0.00 \%$ respectively for the wet and dry seasons. At the upper zone, a similar trend of higher values in the wet than dry season was also observed with values ranging from 0.021 and $0.05 \mathrm{mg} / \mathrm{kg}$ with a mean of $0.03 \pm 0.01 \mathrm{mg} / \mathrm{kg}$ while the dry season value was also uniform at $0.01 \mathrm{mg} / \mathrm{kg}$ with a mean of $0.01 \pm 0.00 \mathrm{mg} / \mathrm{kg}$. The coefficients of variation within the zone were $34.82 \%$ and $0 \%$ respectively for the wet and dry seasons. Similar to the chromium metal, there appeared to be a fairly uniform mean distribution of the metal lead across the zones. In wet and dry seasons, the mean distribution of lead in the organism was observed to be in the order of middle $(0.04 \mathrm{mg} / \mathrm{kg})>$ lower $(0.03 \mathrm{mg} / \mathrm{kg})=$ upper $(0.03 \mathrm{mg} / \mathrm{kg})$, while the dry season had uniform distribution of $0.01 \mathrm{mg} / \mathrm{kg}$ across the zones (Fig. 3e).

\section{Zinc (Zn)}

Zinc in the tissue of Tympanotonus fuscatus occurred in considerably higher concentrations than other trace metals monitored in this study except for copper. Generally, the concentrations of zinc varied between 0.294 to 0.394 in the wet and $1.55-3.00 \mathrm{mg} / \mathrm{kg}$ in the dry season. In the lower reach zone, the wet season values ranged from $0.385-0.394$ $\mathrm{mg} / \mathrm{kg}$ with a mean of $0.39 \pm 0.00 \mathrm{mg} / \mathrm{kg}$ while the dry season value ranged from 2.76 to $3.30 \mathrm{mg} / \mathrm{kg}$ with a mean of $2.99 \pm 0.23 \mathrm{mg} / \mathrm{kg}$ (Fig. 3f). The coefficients of variation within the zone were $0.95 \%$ and $7.66 \%$ respectively for the wet and dry seasons. In the middle zone, the wet season values ranged from 0.294 to $0.335 \mathrm{mg} / \mathrm{kg}$ with a mean of 0.330 $\pm 0.020 \mathrm{mg} / \mathrm{kg}$ while the dry season values ranged from 1.55 to $3.00 \mathrm{mg} / \mathrm{kg}$ with a mean of $2.55 \pm 0.58 \mathrm{mg} / \mathrm{kg}$. The coefficients of variation within the zone were $5.86 \%$ and $22.89 \%$ respectively for the wet and dry seasons. At the upper zone, the wet season values ranged from $0.306-0.392 \mathrm{mg} / \mathrm{kg}$ with a mean of $0.35 \pm 0.04 \mathrm{mg} / \mathrm{kg}$ while the dry season value ranged from $2.41-2.92 \mathrm{mg} / \mathrm{kg}$ with a mean of $2.67 \pm 0.21$ $\mathrm{mg} / \mathrm{kg}$. The coefficients of variation within the zone were $10.09 \%$ and $7.80 \%$ respectively for the wet and dry seasons (Fig. 3f). Similar to vanadium, the general trend in the con- centration of zinc is that of higher concentration observed during the dry season that wet season. The order of magnitude of variation ranged between 5 and 7 . There appeared to be a significant seasonal mean distribution of $\mathrm{Zn}$ across the zone which however followed a similar pattern for both seasons. Thus in the wet season, the distribution of zinc in the tissue was in the order of the lower $(0.39 \mathrm{mg} / \mathrm{kg})>$ upper $(0.35 \mathrm{mg} / \mathrm{kg})>$ middle $(0.33 \mathrm{mg} / \mathrm{kg})$, while for the dry season values were in the similar order of the lower (2.99 $\mathrm{mg} / \mathrm{kg})>\operatorname{upper}(2.67 \mathrm{mg} / \mathrm{kg})>$ middle $(2.55 \mathrm{mg} / \mathrm{kg})$ Fig. (3f).

\section{Copper (Cu)}

Copper was available in both seasons in the tissue of Tympanotonus fuscatus. Generally, the concentrations of copper varied between $0.63-0.94 \mathrm{mg} / \mathrm{kg}$ in the wet and 3.76 - $8.78 \mathrm{mg} / \mathrm{kg}$ during the dry season (Fig. 3g). In the lower reach, wet season concentrations ranged from $0.78-0.94$ $\mathrm{mg} / \mathrm{kg}$ with a mean of $0.84 \pm 0.07 \mathrm{mg} / \mathrm{kg}$ while the dry season value ranged from $8.10-8.83 \times 8.21 \pm 0.10 \mathrm{mg} / \mathrm{kg}$. The coefficients of variation within the zone were $8.34 \%$ and $1.22 \%$ respectively for the wet and dry seasons. In the middle zone, the wet season values ranged from 0.54 to $0.68 x$ $0.62 \pm 0.05 \mathrm{mg} / \mathrm{kg}$ while the dry season value ranged from $3.76-8.78 \times 7.39 \pm 2.09 \mathrm{mg} / \mathrm{kg}$. The coefficients of variation within the zone were $8.27 \%$ and $28.40 \%$ respectively for the wet and dry seasons. At the upper zone, the wet season values ranged from $0.56-0.69 \times 0.63 \pm 0.06 \_\mathrm{mg} / \mathrm{kg}$ while the dry season values ranged from $6.02-8.53 \times 7.77 \pm 1.23$ $\mathrm{mg} / \mathrm{kg}$. The coefficients of variation within the zone were $8.86 \%$ and $15.94 \%$ respectively for the wet and dry seasons. As was observed for zinc and vanadium, copper exhibited higher concentrations during the dry season than wet season. The magnitude of seasonal difference was about 8 folds. However, within the three zones, similar pattern of distribution was observed for both seasons. Thus, in the wet season, the distribution of the copper in the organism was in the decreasing order of concentration with lower $(0.84 \mathrm{mg} / \mathrm{kg})>$ upper $(0.63 \mathrm{mg} / \mathrm{kg})>$ middle $(0.62 \mathrm{mg} / \mathrm{kg})$ and dry season concentrations were also in the decreasing order of the lower $(8.21 \mathrm{mg} / \mathrm{kg})>$ upper $(7.77 \mathrm{mg} / \mathrm{kg})>$ middle $(7.39 \mathrm{mg} / \mathrm{kg})$ respectively (Fig. 3g).

Similarly, the entire variable (THC and heavy metals) for periwinkle demonstrated significance between wet and dry season (Table 1).

\section{Bioaccumulation Factor}

The bioaccumulation factor for THC burden in periwinkle indicated generally more bio-accumulated in the organism during the wet season that during the dry season and the distribution pattern of THC burden between the ecological zones being in the order of Middle (23.3) > Lower (15.63) > Upper (8.41) and Upper $0.15>$ Lower $(0.014)=$ middle (0.014) for wet and dry seasons respectively (Table 1).

Correspondingly, the bioaccumulation factor for heavy metals was observed to be higher in the wet than in the dry season for all the metals species evaluated. In the Lower reach the BAF for wet and dry seasons demonstrated a sequence of $\mathrm{Zn}(2.23)>\mathrm{Pb}(2.14)>\mathrm{Cd}(0.33)>\mathrm{V}(0.29)>$ $\mathrm{Cr}(0.03)$ and $\mathrm{Zn}(0.016)>\mathrm{Pb}(0)=\mathrm{Cd}(0)=\mathrm{V}(0)=\mathrm{Cr}(0)$ respectively. In the Middle reach the BAF pattern for wet and 
Table 2. The Seasonal Comparison of Variable for Sediment and Periwinkle (Student $t$ - test, $t$ Critical Value $=\mathbf{2 . 1 0}$ @ 0.05)

\begin{tabular}{|c|c|c|}
\hline & Sediment & Periwinkle \\
\hline \hline $\mathrm{THC}$ & 2.35 & -2.84 \\
\hline $\mathrm{Cr}$ & -3.48 & -2.42 \\
\hline $\mathrm{Cd}$ & -9.60 & 2.51 \\
\hline $\mathrm{V}$ & -0.26 & $7.73 \mathrm{E}+15$ \\
\hline $\mathrm{Pb}$ & -1.48 & -3.88 \\
\hline $\mathrm{Zn}$ & 10.86 & 15.84 \\
\hline $\mathrm{Cu}$ & 2.80 & 13.81 \\
\hline
\end{tabular}

dry seasons were $\mathrm{Pb}(3.95)>\mathrm{Zn}(1.75)>\mathrm{Cd}(0.45)>\mathrm{Cr}(0.35)$ $>\mathrm{V}(0.00)$ and $\mathrm{Zn}(0.013)>\mathrm{Cr}(0)=\mathrm{Cd}(0)=\mathrm{V}(0)=\mathrm{Pb}(0)$ respectively. Similarly, the Upper reach zone had BAF distribution amongst the metal in the respective order of $\mathrm{Zn}(1.97)$ $>\mathrm{Pb}(1.87)>\mathrm{V}(0.43)>\mathrm{Cd}(0.42)>\mathrm{Cr}(0.043)$. and $\mathrm{Zn}(0.013)>$ $\mathrm{Pb}(0)=\mathrm{V}(0)=\mathrm{Cd}(0)=\mathrm{Cr}(0)$ for wet and dry seasons (Table 2).

\section{MODELLING}

A mathematical model of biological processes tends to be used for one of the three purposes. An increasing order of sophistication, these are description, explanation and prediction: a descriptive model describes what has happened in mathematical terms, an explanatory model explains this in terms of parameters of biological signification and a predictive model gives a guide to what may be expected in the future (Freeman, 1977).

For this study, the mathematical model for explaining the correlation between the mean concentrations of contaminants in organism and sediment has been found to follow a linear regressional equation of the form:

$$
\mathrm{Y}=\mathrm{a}+\mathrm{bx}
$$

Where:

$\mathbf{Y}$ is the Mean contaminant in the organism.

$\mathbf{a}$ and $\mathbf{b}$ are linear regression coefficients corresponding to the $y$ intercept and slope respectively.

$\mathbf{x}$ is the extract estimate of available contaminant in the sediment.

Applying the model equation in the establishment of interrelationship between the Total Hydrocarbon Content in the organism (periwinkle) gave rise to the following relationships.

The regression analysis between THC concentration in tissues and sediment was significant $(\mathrm{P}<0.05)$. THC concentration in periwinkle for example increased by $0.38 \%$ per unit increase in sediment THC concentration. Sediment THC values might be contributing to the tissue THC for values of THC above 2,338.12 mg/kg in the tissue. However, testing the significance by the determination of the coefficient $r^{2}$ showed that only $2 \%$ of the variation in tissue concentration may be attributable to sediment THC load. THC values in the tissue of 2,338.12 $\mathrm{mg} / \mathrm{kg}$ and below are not dependent on the concentration of the THC in the sediment.

The regression equation given for $\mathrm{THC}$ in the tissue of periwinkle and sediment is given by.

$$
\mathrm{P}=2,338.12+0.38 X\left(\mathrm{r}^{2}=0.02, \mathrm{n}=9\right)
$$

\section{CHROMIUM CONCENTRATION IN TYMPANOTO- NUS FUSCATUS}

For chromium the regression analysis between its concentration in the organism and sediment was significant $(\mathrm{P}<0.05)$. Chromium concentrations increased by 0.02 per unit increase in the sediment chromium concentrations. The concentration of Chromium in sediment might be contributing also to the concentration in the organism for values of chromium above $0.02 \mathrm{mg} / \mathrm{kg}$ in the organism. Also testing the significance of the determination coefficient $r^{2}$ showed that only $3.8 \%$ of the variation in the concentration of chromium in the organism may be attributable to the concentration of chromium in the sediment. This implied that chromium values in the organism of 0.02 and below are not dependent on the chromium in the sediment. The regression equation given for chromium in the organism and sediment is given by:

$$
\mathrm{P}=0.02+0.04 \mathrm{X}\left(\mathrm{r}^{2}=0.038, \mathrm{n}=9\right)
$$

\section{CADMIUM IN PERIWINKLE TYMPANOTONUS FUSCATUS}

There was a negative correlation between tissue concentration of cadmium and concentration in the sediment. Thus cadmium concentrations decreased by 0.10 per unit increase in the sediment chromium concentrations. However, testing the significance of the determination coefficient $r^{2}$ showed that about $2 \%$ of the variation in tissue concentration may be attributable to sediment cadmium load. Cadmium values in organisms of $0.01 \mathrm{mg} / \mathrm{kg}$ and below are therefore not dependent on the cadmium in the sediment. The regression equation for Cadmium in the organism and the sediment is give by:

$$
\mathrm{P}=0.005-0.10 \times\left(\mathrm{r}^{2}=0.02, \mathrm{n}=9\right)
$$

\section{VANADIUM CONCENTRATION IN TYMPANOTO- NUS FUSCATUS}

The regression analysis showed negative correlation. The vanadium concentration in tissue reduces by 1.79 per unit increase in vanadium concentration. Sediment vanadium values might be contributing to that in the organism for values above $0.03 \mathrm{mg} / \mathrm{kg}$ in the organism. However testing the significance of the determination coefficient $r^{2}$ showed that no variation in concentration of vanadium in the organism may be attributable to sediment vanadium load. Vanadium values in the organism of $0.03 \mathrm{mg} / \mathrm{kg}$ and below are therefore not dependent on sediment vanadium. The regression equation given for this relationship is given by:

$P=0.03-1.79 \times 10^{-15} \times\left(r^{2}=-17.7, n=9\right)$ 


\section{LEAD CONCENTRATION IN TYMPANOTONUS FUSCATUS}

For lead the regression analysis between its concentration in the organism and sediment was significant $(\mathrm{P}<0.05)$. Lead concentrations reduce by 1.47 per unit increase in the sediment lead concentrations. The concentration of lead in sediment might be contributing also to the concentration in the organism for values of chromium above $0.039 \mathrm{mg} / \mathrm{kg}$ in the organism. Also testing the significance of the determination coefficient $\mathrm{r}^{2}$ showed that $34 \%$ of the variation in the concentration of lead in the organism may be attributable to the concentration of lead in the sediment. This implied that lead values in the organism of 0.01 and below are not dependent on the lead in the sediment. The regression equation given for lead in the organism and sediment is given by:

$$
\mathrm{P}=0.039-1.47 \mathrm{X}\left(\mathrm{r}^{2}=0.34, \mathrm{n}=9\right)
$$

\section{ZINC CONCENTRATION IN TYMPANOTONUS FUSCATUS}

The regression analysis showed significant correlation. The zinc concentration in tissue increase by 0.023 per unit increase in sediment zinc concentration. Sediment zinc values might be contributing to that in the organism for values above $1.51 \mathrm{mg} / \mathrm{kg}$ in the organism. However, testing the significance of the determination coefficient $\mathrm{r}^{2}$ showed that only $0.05 \%$ of the variation in concentration of zinc in the organism may be attributable to sediment zinc load. Zinc values in the organism of $1.51 \mathrm{mg} / \mathrm{kg}$ and below are therefore not dependent on sediment zinc. The regression equation given for this relationship is given by:

$$
\mathrm{P}=1.51+0.30 \times\left(\mathrm{r}^{2}=0.0005, \mathrm{n}=9\right) \text {. }
$$

\section{COPPER CONCENTRATION IN TYMPANOTONUS FUSCATUS}

The regression analysis showed positive correlation. The copper concentration in tissue increases by 7.5 per unit increase in copper concentration. Sediment copper values might be contributing to that in the organism for values above $3.89 \mathrm{mg} / \mathrm{kg}$ in the organism. However, testing the significance of the determination coefficient $\mathrm{r}^{2}$ showed that only approximately $1.0 \%$ of the variation in concentration of copper in the organism may be attributable to sediment copper load. Copper values in the organism of $3.89 \mathrm{mg} / \mathrm{kg}$ and below are therefore not dependent on sediment copper. The regression equation given for this relationship is given by:

$$
\mathrm{P}=3.89+7.5 \mathrm{X}\left(\mathrm{r}^{2}=0.01, \mathrm{n}=9\right)
$$

\section{DISCUSSION}

Generally, the higher levels of THC concentrations in the dry $(411.53 \pm 118.77 \mathrm{mg} / \mathrm{kg})$ than in the wet $(400 \pm 375.50$ $\mathrm{mg} / \mathrm{kg}$ ) season may be attributed to the dilution effect associated with the wet season. This scenario had been reported in similar studies in the Niger Delta region and had been attributed to reduction in the volume of water following the high evapo-transporation rate that characterise the equatorial latitude [22-24].

The observed high concentration of THC in the upper reach zone of the river system during the wet season may be attributed to the massive release of trapped THC from the crude oil related activities of the area coupled with the runoff from other contaminated landmass adjoining the Upper reach that is characterised by relative high fresh water input than other arms of the drainage basin. Similar studies have shown that high THC concentration was observed in wet than during the dry season [25].

The distribution of THC within the zone was also observed to be very uneven at the ecological zones more so in the wet season. Thus the seasonal patterns demonstrated variation within the ecological zones (with coefficient of variation) for the three ecological zones being Upper - 96\%, Middle $-119 \%$ and Lower- $94 \%$ and Upper -19\%, Middle $29 \%$ and Lower $29 \%$ for wet and dry seasons respectively. The variations in concentrations within zones in dry season demonstrated narrow variation against the wet with wider variation; and similarly concentrations were relatively higher in the dry season than was observed for the wet season. . This narrow variation in the dry season indicates even distribution of THC in the dry season than in the wet season. This further suggests the role of seasonal difference in the distribution of THC in the water body. Similar variations in THC with seasons were demonstrated for Bonny/New calabar river systems with values ranging from $0-798.25$ in wet season and $246.92-571.63 \mathrm{mg} / \mathrm{kg}$ in dry season [26, 27]. The presence of T. fuscatus in the system in spite of the high THC demonstrates the propensity for the organism to withstand the stress under the condition. However Chindah and Nduaguibe [27] posited that the survival of the gastropod at high THC may also cause harm. This harm may be in the area of reproductive success as juveniles were hardly seen in the most of the study station. This may account for the poor yield in fish, shrimp and periwinkle in the system as complained by the fisher folks [28].

In addition the higher values in THC observed for the wet $(1,704.73-4,170.50 \mathrm{mg} / \mathrm{kg})$ and in the dry season $(1,610.02-2,229.00 \mathrm{mg} / \mathrm{kg})$ in Tympanotonus fuscatus may be attributed to a number of factors arising from the flow characteristics of the river system. Furthermore, it is expected that the wet season which is a period of high flows may have carried large volume of suspended sediments and run-offs from municipal and industrial sources (petrogenic sources such as garages) leading to increased THC load and other contaminants in the water body thereby accounting for the higher values observed in the wet than in dry seasons. It is also possible that browsing intensity by Tympanotonus fuscatus may be contributory to the higher concentrations observed in the wet than in the dry season. The degree and extent of contamination in each coastal system have been attributed to several factors such as variations in inputs and dynamics, also reactivity of suspended particles and superficial sediments [25]. Many rivers are characterized by contrasting seasonal flows and freshwater discharge with wet season being much higher than that occurring during the rest of the year. This may be responsible for transport of fluvial solids to the estuaries mainly in wet season during periods of high flows and contributed to re-suspension of crude oil to the surface. This is congruent with the submission of Abarnou et al., [18] which contends that suspended particulate matter is normally responsible for the transport and distribution of hydrophobic contaminants in the aquatic environment. 

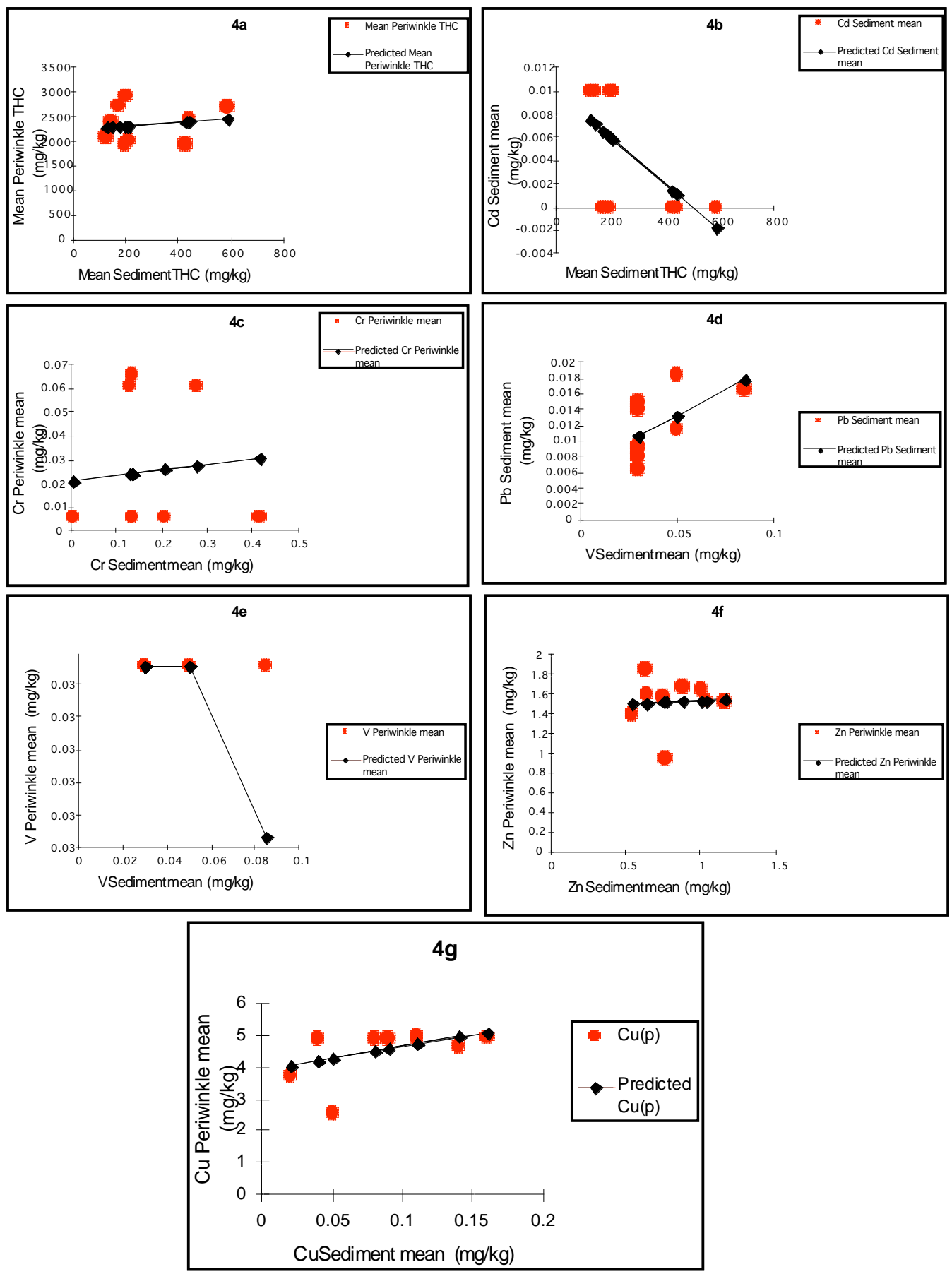

Fig (4a-g). The regressional predictive plot on periwinkle - Tympanotonus fuscastus tissue burden on Total Hydrocarbon and heavy metal concentrations in Periwinkle.

Similarly, the seasonal pattern of THC concentration and the coefficient of variation for Tympanotonus fuscatus for the three ecological zones Lower $-38 \%$, Middle $-22 \%$ and Upper $-19 \%$ and lower $-4 \%$, middle $-10 \%$ and Upper $-7 \%$ for the wet and dry seasons respectively suggest a narrower and more even distribution with the ecological zones in the dry season than in the wet season. This further provides evidence on the role of season in the distribution of THC in the system. The higher concentrations of THC observed in the tissue against the sediment for the seasons also suggests that the organisms overtime, through the process of feeding and other activities have bi-accumulated THC in the body tissue of organism. $[29,30]$ reported similar trend while working on crude oil impacted environment in oysters. Statistical analysis of the results showed a positive correlation between the THC in sediment and the Tympanotonus fuscatus (regression coefficient $\left(r^{2}=0.02\right)$. This evidence indicates that the source of THC found in the organism is primarily from the sediment. Other studies have reported similar observations especially at $[31,32]$ estuaries. This is further confirmed by the fact that $2.0 \%$ of the tissue THC concentration is associated with THC from sediment [29]. The finding in 
this study also showed that the tissue of Tympanotonus fuscastus had higher THC than in the sediment suggesting bio-accumulation by the organism [33-35].

Some heavy metal species particularly cadmium, zinc, lead and copper were observed to have relatively higher concentrations in both organism and sediment than others. These heavy metals are closely associated with crude oil and its processed products and to extent municipal waste discharges [28]. This may account for the predominance of these heavy metals in the system especially within the vicinity of the oil industries related activities and municipal waste charges [28, 32]. Nevertheless, some studies conducted elsewhere in the Niger Delta region reported similar trends as observed in this study [36-39]. In the contrary, Silver and Arsenic were reported as the heavy metals with highest concentrations in a marine environment at Galveston Bay, Texas [52]. In spite of the fact this study did not consider these heavy metals; it is however presumed that the differences may also be due to the nature of human activities and wastes discharged in the study area.

The observed seasonal differences in heavy metal concentrations in sediment with $\mathrm{Cd}, \mathrm{Cr}$, and $\mathrm{Pb}$ having higher values in the wet than in the dry season, with $\mathrm{Zn}$, and $\mathrm{Cu}$ being the opposite is difficult to explain. Similarly, heavy metal burden in Tympanotonus fuscatus with higher concentrations of $\mathrm{Cr}, \mathrm{Cd}$, and $\mathrm{Pb}$ in the wet than in the dry season and the contrary observed for $\mathrm{V}, \mathrm{Zn}$, and $\mathrm{Cu}$ seem to follow closely the pattern observed for sediment. However, this scenario may be explained, on the fact that the THC recorded in the sediment and tissue may be of crude oil in origin, since crude oil is naturally associated with the heavy metals [36, 37, 40, 41]. Secondly, it is possible that storm water from adjacent development may be contributory to the levels of heavy metals observed in the sediment and tissue of the Tympanotonus fuscatus. Another factor likely to affect the uptake of heavy metals in the tissue of the organism may be associated with the feeding habit, development stages, reproductive condition, and other physicochemical attributes of the system [42-44]. Philip, [45] contended that some abiotic factors such as $\mathrm{pH}$, temperature and salinity may affect the uptake of heavy metals in a system. This may account for differences in the presence and uptake of some of the heavy metals as these factors particularly $\mathrm{pH}$ and salinity in these ecological zones varied considerably.

The observed trend in the heavy metals in periwinkle tissue and sediment between the ecological zones with $\mathrm{Cu}$ and $\mathrm{Zn}$ recording highest concentrations in the lower zone, while only $\mathrm{Cu}$ and $\mathrm{Zn}$ recorded highest concentrations in the upper and lower zones respectively in the dry season. This affirms the importance of seasonal dynamics in the spatiotemporal variability in heavy metal distribution. This also suggests that the contributing factors to the heavy metal availability come from the same possible source(s). This contention is in agreement with the with the proposition of Fernandes, [46] and [47], positing that the distribution of heavy metals in sediment is affected by three factors namely, the relative position of the sampling location to pollutant source, environmental characteristics of the fluvial (freshwater) environment and environmental characteristics of the marine environment. This may account for the apparent consistent pattern in the $\mathrm{BAF}$ with $\mathrm{Zn}, \mathrm{Pb}$ and $\mathrm{Cd}$ being the leading metals mostly bio-accumulated by the organism for the 3 ecological zones in wet season. Our observation is partially supported by the work of [48] that reported bio-accumulation sequence of $\mathrm{Cd}>\mathrm{Fe}>\mathrm{Cu}>\mathrm{Zn}$ in Periophthalmus waltoni after 60 days of exposure. demonstrated differences in preferential bioaccumulation of heavy metals in the tissue of gastropod Brotia costula and Melanoides tuberculata, with Brotia costula indicating better efficiency in accumulating of $\mathrm{Cu}$ and $\mathrm{Zn}$ and Melanoides tuberculata for $\mathrm{Cu}$. This study may impart explain the differences in species of metal burden observed in the different ecological zones, following the differences in the water quality of the ecological zones particularly $\mathrm{pH}$ and salinity [49], posited conjectured that the bioavailability of metals greatly depends on hardness of water, $\mathrm{pH}$ and the acid-volatile sulphide of the water and sediment. Thus these factors obviously differed with the ecological zones [15] and is likely to contribute to the differences observed in metal species bio-accumulated.

In all, the organism has the tendency to bio-accumulate with preferences for some heavy metals depending on the ecological area and season. This further demonstrates that the organism possesses bio-indicator attributes for monitoring metals in the Niger Delta region. Similar propositions have been put forward for sediment $[50,51]$ and benthic dwelling fish [19-21] other benthic dwelling organism [27, 28].

This scenerio is appropriately observed from the regression model, for THC and various species of heavy metals suggests that even though sources for these components are basically anthropogenic or human activity related sources of intake contributing to the tissue burden are not entirely from the sediment but possibly also from the water column. This underscores the fact that food and medium in which the organism lives play an important role in tissue burden of contaminants in the ecosystem.

\section{ACKNOWLEDGEMENTS}

We sincerely thank the staff of the Institute of Pollution Studies Rivers State University of Science and Technology and $\mathrm{Mr}$ Ikoro Udona and Awaini Osuamkpe especially for providing access to laboratory facilities. More thanks to the three unanimous reviewers for the helpful comments and suggestions on the manuscript.

\section{REFERENCES}

[1] Adoki A, Orugbani T. Influence of nitrogenous fertilizer plant effluents on growth of selected farm crops in soils polluted with crude petroleum hydrocarbons. Afr J Agric Res 2007; 2 (11): 56973.

[2] Ana GREE, Sridhar MKC, Emerole GOA. Comparative assessment of soil pollution by polycyclic aromatic hydrocarbons in two Niger Delta communities, Nigeria. Afr J Pure Appl Chem 2009; 3 (3): 3141.

[3] Anyakora C, Coker H. Assessment of polynuclear aromatic hydrocarbon content in four species of fish in the Niger Delta by gas chromatography/mass spectrometry. Afr J Biotechnol 2007; 6(6): 737-43.

[4] Fabris JG, Richardson BJ, O'Sullivan JE, Brown FC. Estimation of cadmium, lead and mercury concentration in estuarine waters using the mussel Mytilus edulis planulatus. L. Environ Toxicol Water Qual 1994; 9: 183-92. 
[5] Oaie G, Szobotka S, Staanicaa ÄA, et al. Environmental assessment of River Danube between 1995 and 1997. Geo-Eco-Marina 1999; 3-89.

[6] Winkels HJ, Marin G, Van der Scheer A, Van Munster G. Geochronology degree of pollution of priority pollutants in sedimentation zones of the Danube Delta. Report RWS-Directorate Flevoland RBA 1995-34 LIO, Lelystad, The Netherlands, 1995.

[7] Tuvikene A, Huuskonen S, Koponen K, Ritola O, Mauer Ü, Lindström-Seppä P. Oil shale processing as a source of aquatic pollution: monitoring of the biologic effects in caged and feral freshwater fish. Environ Health Perspect 1999; 107: 745-52.

[8] Wilcox BHR. Angiosperm flora of the Niger Delta Mangal: a taxonomic review. Proc. Workshop on the Niger Delta Mangrove Ecosystem, May 1980, Port Harcourt 19- 23, 1985. p. 190.

[9] Herbert P, Ana LSA, João MJ, Santos L, Alves A. Determination of semi-volatile priority pollutants in landfill leachates and sediments using microwave-assisted headspace solid-phase microextraction. Anal Bioanal Chem 2006; 386: 324-31.

[10] Fernandes HM. Heavy metal distribution in sediments and ecological risk assessment: the role of magnetic processes in reducing metal toxicity in bottom sediments. Environ Pollut 1997; 97(3): 317-25.

[11] Goldberg ED. The mussel watch concept. Environ Monit Assess 1986; 7: 91-103.

[12] Soto M, Ireland MP, Marig'omez I. The contribution of metal shell-weight index in target-tissues to metal body burden in sentinel marine mollusc. 2. Mytilus gallopro“incialis. Sci Total Environ 1997; 198: 1-160.

[13] Widdows J, Donkin P, Brinsley MD, et al. Marine Ecol Prog Ser 1995; 127:131-48.

[14] Chindah AC. The effect of industrial activities on the periphyton community at the upper reaches of New Calabar River, Niger Delta, Nigeria. Water Res 1998; 32 (4): 1137-43.

[15] Research Planning Institute -RPI. Environmental baseline studies for establishment of control criteria and standards against petroleum related pollution in Nigeria, RPI/84/4/15-7, 1985.

[16] Gobo AE, Ubong, IU, Ede PN. Rainfall intensity analysis as a tool for hydrological and agricultural practises in Southern Nigeria. Int J Meterol 2008; 33(334): 343-50.

[17] Gobo AE. Relationship between rainfall trends and flooding in the niger -benue river basins. J Meteorol 1988; 13 (132): 220-4.

[18] Abarnou AJ, Avoine J, Dupont JP, Lafite R, Simon S. Role of suspended sediment on the distribution of PCB in the Seine Estuary. (France) Continental Shelf Res 1987; 7: 1345-50.

[19] Agbozu IE, Ekweozor IKE. Heavy metals in a nontidal freshwater swamp in the Niger Delta areas of Nigeria. Afr J Sci 2001; 2: 17582 .

[20] Agbozu IE, Ekweozor IKE. Heavy metals in sediments from lower Taylor Creek in the Niger Delta area of Nigeria. Afr J Sci 2004; 5 (1): 1043-49.

[21] Agbozu IE, Ekweozor IKE, Opuene K. Survey of heavy metals in the catfish Synodontis clarias. Int J Environ Sci Tech 2007; 4 (1): 93-7.

[22] Chindah AC, Braide SA. Cadmium and lead concentrations in fish of a brackish wetland upper Bonny estuary, Niger Delta. J Niger Environ Soc (JNES) 2003; 1(3): 399-405.

[23] Niger Delta Environmental Survey -NDES. Ecological zonation and habitat classification. $2^{\text {nd }}$ Phase Report 2000; vol. 1: pp. 1-66.

[24] Niger Delta Development Commission -NDDC. Biodiversity of the Niger Delta environment Niger Delta Development Commission Master Plan Project Final report 2004; pp. 123-237.

[25] Olsen CR, Larsen IL, Mulholland PJ, et al. The concept of an equilibrium surface applied to particles sources and contamination distribution in estuarine sediment. Estuar 1993; 16: 683-96.

[26] Chindah AC, Braide SA, Nduaguibe U. Tolerance of periwinkle (Tympanotonus fuscatus and Shrimp (Palemonetes africanus Balsa) to waste water from bonny light crude oil tank farm. Polish J Environ Prot Nat Res 2000; 21/22: 61-72.

[27] Chindah AC, Nduaguibe U. Effects of tankfarm waste water on water quality and periphyton lower Bonny River, Niger Delta, Nigeria. J Niger Environ Soc (JNES) 2003; 1(2): 206-22.
[28] Chindah AC, Sibeudu OC. Levels of Hydrocarbons and heavy metals in sediment and a decapod crustacean (Crab - Uca Tangeri ) in the Bonny/New Calabar River Estuary, Niger Delta. Pollut J Environ Protect 2003; 25/26: 55-71.

[29] Metwally ME, Al-Muzaini S, Jacob PG, et al. Petroleum hydrocarbon and related heavy metals in the near shore marine sediments in Kuwait. Environ Int 1997; 23(1): 115-21.

[30] Micheel J, Zengel S. Monitoring of oysters and sediments in Acajutala, El Salvador. Mar Pollut Bull 1998; 36(4): 256.

[31] Gbaruko BC, Friday OU. Bioaccumulation of heavy metals in some fauna and flora. Int J Environ Sci Tech 2007; 4(2): 197-202.

[32] Chindah AC, Sibeudu OC, Braide SA, Onyebuchi C. Distribution of hydrocarbons and heavy metals in sediment and a crustacean (Shrimps - Penaeus notialis) from the bonny/new calabar river estuary, Niger Delta. Afr J Environ Assess Manage 2004; 9: 1-17.

[33] Eisenberg M, Topping JJ. Trace metal residues in shellfish from maryland waters. 1976-1980. J Environ Sci Health B 1984; 19: 649-71.

[34] Presley BJ, Taylor RJ, Boothe PN. Trace metal concentrations in sediments of the Eastern Mississippi Bight. Mar Environ Res 1992; 33: $267-82$

[35] Dambo WB. Tolerance of the Periwinkles Pachymelania aurita (Muller) and Tympanotonus fuscatus (Linne) to refined oils. J Environ Pollut 1992; 79: 293-6.

[36] Kakulu SE, Osibanjo O. Trace heavy metal pollutional studies in sediments in the Niger delta area of Nigeria. J Chem Soc Niger 1988; 13: 9-15.

[37] Kakulu SE, Osibanjo O, Ajayi SO. Trace metal content of Fish and Shellfishes of the Niger Delta Area of Nigeria. Environ Int 1987; 13: 247-51

[38] Davies OA, Allison ME, Uyi HS. Bioaccumulation of heavy metals in water, sediment and periwinkle (Tympanotonus fuscatus var radula) from the Elechi Creek, Niger Delta. Afr J Biotech 2006; 5 (10): 968-73.

[39] Eja ME, Ogri ORA, Arikpo GE. Bioconcentration of heavy metals in surface sediments from the Great kwa Rivers Estuary,Calabar, South Eastern Nig. J Niger Environ Soc 2003; (2): 247-56.

[40] Izonfuo WAI, Chindah AC, Braide SA, Iyalla IA. An assessment of sediment quality at the vicinity of marine landing jetties at the middle reaches of Bonny estuary, Niger Delta. Sci Afr 2004: 3(2), 110 .

[41] Ndiokwere CL, Guinn VP. Determination of some toxic trace metals in Nigerian river and harbor water samples by neutron activation analysis. J Radioanal Nucl Chem Artic 1983; 79: 147-51.

[42] Okoye BCO. Heavy metals and organisms in the Lagos Lagoon. Int J Environ Stud 1991; 37: 292-385.

[43] Pillai VK, Valsala KK. Seasonal variations of some metals in bivalve mollusc sunetta scripta from the cochin coastal waters. Indian J Mar Sci 1995; 24: 113-5.

[44] Ni IH, Chan SM, Wang WX. Influences of salinity on the biokinetics of $\mathrm{Cd}$, Se and $\mathrm{Zn}$ in the intertidal mudskipperPeriophthalmus contonensis. Chemosphere 2005; 61: 1607-17.

[45] Philips DJH. The common mussel, mytilus edulis as an indicator of pollution by zinc, cadmium, lead, and copper. ii. relationship of metals in the mussel to those discharges by industry. Mar Biol 1976; 38: 71-80.

[46] Ferreira AM, Vale C. The importance of runoff to DDT and PCB inputs to the sado estuary and ria formosa. Neth J Aqua Ecol 1995; 29 (3-4): 211-6.

[47] Claude RJ, Azokwu M. Heavy metals in the bivalve anadara (Senilia senilis) from Nigeria. Mar Pollut Bull 1999; 38(7): 618-22.

[48] Bu-Olayan AH, Thomas BY. Trace metals toxicity and bioaccumulation in mudskipper Periphthalmus waltoni Koumans 1941(Gobiidae: perciformes). Turk J Fish Aqua Sci 2008; 8: 215-8.

[49] Besser JM, Ingersoll CG, Giery JP. Effects of spatial and temporal variation of acid-volatile sulphide on the bioavailability of copper and zinc in freshwater sediment. Environ Technol Chem 1996; 15 286-93.

[50] Ekweozor IKE. A review of the effect of oil pollution in West African environment. Dis Innov 1989; 1(3): 2-14.

[51] Snowden RJ, Ekweozor IKE. The impact of a minor spillage in the Estuarine Niger Delta. Mar Pollut Bull1987; 18(11): 595-9. 
[52] Jiann K, Presley BJ. Variation in trace metal concentrations in american oysters (Crassostrea virginica) collected from galveston bay. Texas Est 1997; 20(4): 710-24.
[53] Institute of Pollution Studies -IPS. Environmental Data Acquisition of some NNPC Operational Area. RSUST/IPS/TR/89/03, 1989.

Received: March 30, 2009

Revised: April 28, 2009

Accepted: July 07, 2009

(C) Chindah et al.; Licensee Bentham Open.

This is an open access article licensed under the terms of the Creative Commons Attribution Non-Commercial License (http://creativecommons.org/licenses/by-nc/3.0/) which permits unrestricted, non-commercial use, distribution and reproduction in any medium, provided the work is properly cited. 